\title{
Assessment of the Impact of WAEMU Common External Tariff (CET) in Senegal
}

\author{
Ibrahima Thione Diop \\ Faculté des Sciences Economiques et de Gestion, Université Cheikh Anta Diop, Dakar, Senegal \\ Email: thionediop@yahoo.fr
}

Received 14 November 2015; accepted 14 December 2015; published 17 December 2015

Copyright (C) 2015 by author and Scientific Research Publishing Inc.

This work is licensed under the Creative Commons Attribution International License (CC BY). http://creativecommons.org/licenses/by/4.0/

(c) (i) Open Access

\section{Abstract}

The adoption of the common external tariff (CET) by ECOWAS member countries is a further step towards the realization of the Customs Union and to the harmonization of trade programs. Senegal has joined the CET in $\mathbf{2 0 0 0}$ to boost its trade with neighboring countries and the rest of the world. At the WAEMU level, the CET establishes a delicate equilibrium between member countries with divergent interests on certain products. However, it is criticized for being unable to provide sufficient protection to production branches and promote the emergence of a real community market. A key challenge of the ECOWAS-CET is to manage to reconcile the concerns of countries that require modifications in some elements of the WAEMU-CET. It is thus important to assess the implementation of the WAEMU-CET in Senegal, to bring out its strengths and weaknesses, in order to better tackle the negotiations on the ECOWAS-CET. The main objective of this study is to engage in such an exercise by focusing on the impact of the CET on public finance. In this paper, we examine the impact of recently implemented Common External Tariff (CET) by ECOWAS on the Senegalese economy. Using a partial equilibrium framework, we have undertaken simulations of CET application on key macroeconomic variables. Our results suggest very strong negative impact on fiscal revenue, inflation, but a dramatic change in tax structure, mainstreaming consumption taxes and VAT at the detriment of collected duties. Our conclusion calls for structural reforms beyond external tariff alignment in order to increase competitiveness and boost exports. A forecasting and simulation model has been developed to measure the impact of the CET on some key macroeconomic variables. Simulations show that a decrease in customs duty rate had a depressive effect on fiscal revenues. The estimated decline in fiscal revenues amounted to nearly CFA F 41 billion and 51.75 billion respectively in 2007 and 2013. However, overall, the positive effect of VAT and consumption taxes outweighs the depressive effect of lower customs duties on fiscal revenues. Thus, the overall impact of the reforms on total fiscal revenues is positive and amounts to 63.78 billion in 2007 and is expected to rise to $\mathbf{7 9 . 9}$ billion in 2013. Regarding price simulations, the findings show that the increase of indirect taxation subsequent to WAEMU reforms led to inflation. Compared to the baseline (unchanged fiscal legislation), consumer price indices and the manufacturing sector price indices grew faster. This upward effect increased over time. In terms of consumer 
prices, the estimated gap amounted to $5.70 \%$ in $2002,5.71 \%$ in 2007 and $6.92 \%$ in 2013 . Regarding prices of manufacturing sector, the differences are more important because they amounted to $6.09 \%$ in $2002,6.19 \%$ in 2007 and $6.56 \%$ in 2013 . While the introduction of the CET has led to a change in the structure of fiscal revenues, it also allowed the realization of fiscal and customs translation in favor of the share of taxes in total fiscal revenues. For a better balance among economic, financial and social functions of taxes on Senegalese economy, the following two recommendations are made: a) improvement of collection performance of direct taxes through a series of actions (increase of human and material resources of fiscal administration, increase of the taxable base through tax compliance promotion strategy that should be especially through improving the quality of public service and the gradual formalization of the informal sector); b) the use of other trade policy instruments (non-tariff measures such as standards, strengthening of the repressive arsenal against fraud, counterfeiting and piracy) to safeguard the national economy.

\section{Keywords}

\section{Common External Tariff, WAEMU, Fiscal Simulation, Economic Integration}

\section{Introduction}

Senegal is a member of the Economic Community of West African States (ECOWAS) and of the West African Economic and Monetary Union (WAEMU), which are two different patterns of regional integration, among the most advanced in Africa. While in the WAEMU, there is a common external tariff (CET), a harmonization of value added tax (VAT) and common sectoral policies, it is not the same situation regarding ECOWAS. Thus, member countries of the WAEMU, which are also members of ECOWAS, are a subset of the latter, with economic and trade ties rather special. This situation renders the integration process among WAEMU member countries more advanced than the one vis-à-vis to other members of ECOWAS. Moreover, the latter organization is the regional entity recognized as sub-regional group of West Africa, under the Cotonou Agreement that defined the Economic Partnership Agreements (EPAs) between Africa and the European Union (EU). Therefore, there is a need of a CET, covering all West African countries as a prerequisite, before signing an EPA with the EU. It is in this context that the Conference of Heads of State and Government of ECOWAS, held in Niamey in 2006, adopted the ECOWAS-CET, which was understood as an extension of the WAEMU-CET, to other member countries of the ECOWAS. Thus, an agreement is required between member States on the architecture of the CET, which integrates and corrects the system set up within the WAEMU. This study aims to critically assess the WAEMU-CET in order to draw relevant lessons for the ECOWAS-CET.

The West African Monetary Union (WAMU) is one of the most successful experiences of economic integration in Sub-Saharan Africa. The WAMU reached a new level following the devaluation of the CFA franc in January 1994, with the harmonization of trade policies of member countries and the adoption of a CET. In Senegal, the adoption of the CET has led to a simplification of tariff structure and a significant tariff reduction. Moreover, in the wake of tariff and fiscal reforms introduced in 2000, a poverty reduction policy was initiated with the implementation of the first phase of the Poverty Reduction Strategy Document (DSRP I) and ongoing development of the Accelerated Growth Strategy (SCA). It was expected through these strategies to create the conditions for achieving the Millennium Development Goals (MDGs), especially halving poverty by 2015.

At the WAEMU level, as an essential component of the Customs Union, the CET established a delicate balance between member countries with divergent interests on certain products. However, it is criticized for being unable to provide sufficient protection to some production branches and promote the emergence of a real community market. The harmonization of tax system within Member States constitutes one of the major objectives of the WAEMU. Thus, after the adoption of a CET, with its accompanying measures, tax regimes of value have added and excise duties have been harmonized, setting up a uniform indirect tax system within the union, which constitutes a guarantee of transparency in intra-community trade. Significant progresses have therefore been made very quickly by WAEMU in the implementation of a favorable fiscal environment, for the creation of commercial and investment flows between different states, especially through the harmonization of taxes on 
consumption and imports. The establishment of the Customs Union (CET and internal liberalization) resulted in a simplification and a significant decline in nominal rates of custom duties. This decline continues with the conclusion of an EPA with the EU, main trade partner of the WAEMU.

The objective of this study is to assess the impact of the implementation of the WAEMU-CET on Senegalese economy, with a particular focus on public finance. The paper is organized as follows. In the Section 2 we review the fiscal and customs harmonization scheme within the WAEMU; the scheme of the Customs Union, the harmonization of internal indirect tax system, and the community investment code are presented. In Section 3, the effects of reforms on recovery in Senegal are presented. Section 4 uses a forecasting and simulation model to measure the impact of reforms within the WAEMU on key macroeconomic variables. The paper ends with a section on conclusions and recommendations.

\section{Characteristic of the Fiscal and Customs Harmonization Scheme}

The Customs Union is characterized, first, by the liberalization of trade within the union, by eliminating tariff and non-tariff barriers to trade among member countries and, second, by the establishment of a CET ${ }^{1}$.

The rules of origin of the transitional system, its financing mode and the schedule of tariff reductions are presented below.

These rules distinguish three types of products:

- Local products originating from the EU Member States namely animal, mineral and vegetable products, which do not undergone any industrial transformation, even if they have undergone an initial transformation designed to preserve them and to facilitate their movement;

- Traditional handicraft products originating from Member States of the Union namely handmade products, with or without the aid of tools, instruments or devices directly operated by the craftsman;

- Industrial products in which are incorporated community raw materials, in quantity, representing at least $60 \%$ of raw materials used.

To finance the transitional preferential regime, it was instituted a Community Solidarity Levy (CSL), whose products are collected and reversed by financial administrations in an account in the name of the WAEMU, domiciled in the books of BCEAO of each Member State. Between July 1996 and April 1999, recoveries made under the CSL amounted to CFA F 31.45 billion. In 1999, an amount of CFA F 12.8 billion, about 40.7\% of CSL, was budgeted to ensure compensation for losses in customs revenues recorded by Member States for the years from 1996 to $1999^{2}$. The CSL rate increased from $0.5 \%$ to $1 \%$.

The schedule of tariff reductions on intra-WAEMU trade is as follows:

$>$ For local and traditional handicraft products: the free movement of franchise rights and entry taxes, since July $1^{\text {st }}, 1996$;

> For approved industrial products, the schedule for the reduction of duties and entry taxes is as follows: $30 \%$ on July $1^{\text {st }}, 1996^{3} ; 60 \%$ on July $1^{\text {st }}, 1997^{4} ; 80 \%$ on January $1^{\text {st }}, 1999^{5}$ and $100 \%$ on January $1^{\text {st }}, 2000^{6}$.

$>$ For non-approved industrial products: reduction of $5 \%$ and then $1 \%$, on entry taxes and duties from July $1^{\text {st }}$, 1996. It should be noted that non-approved products benefit from a discount of $5 \%$ of customs duties. This disposition was not applicable since the implementation of the new rules of origin.

Thus, the schedule agreed by the authorities of the WAEMU for the internal domestic tariff disarmament is respected, and since 1999, the reduction of $80 \%$ is applied in all member states, with the exception of GuineaBissau. The transitional preferential regime of trade within the Union is in its third stage of lowering entry duties $^{7}$. However, it should be noted that since 2000 there was a total liberalization. Since 2006, there was no more reimbursement of losses of customs revenues resulting from the implementation of the WAEMU-CET.

Consequently, the remarkable rise of the approved products is the proof of the interest that enterprises of member countries have in the regime. Senegal, after Côte d'Ivoire, is experiencing a significant rate of applications of approval with $27.5 \%$ of the requests from the Union, a total number of 67 companies for 143 approved

\footnotetext{
${ }^{1}$ Additional Act No 04/96 of May 10, 1996 [1].

${ }^{2}$ WAEMU, Fiscal and custom framework, 1999.

${ }^{3}$ Additional Act No 01/97 of June 23, 1997 [2].

${ }^{4}$ Additional Act No 01/97 of June 23, 1997.

${ }^{5}$ Additional Act No 04/98 of December 30, 1998 [3].

${ }^{6}$ Additional Act No 04/98 of December, 1998.

${ }^{7}$ WAEMU, Fiscal and custom framework, 1999.
} 
products in 1998 (WAEMU, 1999).

The distribution of approved products per production branches shows that the products of chemical industries are those that are more subject to approval by the Commission of the WAEMU (36.9\%), followed by products of food industries (26.2\%), products of construction material industries $(11.1 \%)$, and textiles $(9.8 \%)^{8}$. However, it should be noted that some cases of technical barriers, especially relating to the movement of certain approved products have been reported to the Commission.

Among the objectives set by the WAEMU Treaty in its Article 4, there is the creation of a common market based "on the free movement of persons, goods, services, capital and the right of establishment of persons exercising an independent or salaried activity, as well as on a CET and a common trade policy”.

The scheme of WAEMU-CET is presented through its architecture, its tariff structure and its external tariff dismantling schedule.

The architecture of the WAEMU-CET includes as duties and permanent taxes: customs duties (DD), statistical fee (RS) of $1 \%$ applicable to all products including those exempt from customs duty and from CSL. Regarding temporary duties and taxes, the architecture of the WAEMU-CET includes: degressive protection tax (TDP) (Table 1) and conjuncture import tax (TCI).

The entry into force of the CET was conducted with the following tariff structure for trade between the rest of the world: $0 \%, 5 \%, 10 \%$ and $20 \%$ for customs duties and the $1 \%$ rate for the applicable statistical fee to all products, including those exempt from customs duty, bringing the overall entry duties to $1 \%, 6 \%, 11 \%$ and $21 \%$ respectively for categories $0,1,2$ and 3 . Compared with previous tariff systems, whose maximum tax rates ranged from 22\% in Benin and 65\% in Senegal, it is obvious that the reform undertaken leads to a real simplification and a substantial reduction of taxation in the WAEMU zone.

The tariff structure consists of four tariff rates applicable depending on the type of products that are classified into four categories: $0 \%$ for category 0 ; $5 \%$ for category $1 ; 10 \%$ for category 2 and $20 \%$ for category 3.

This classification came into force in all member countries since January $1^{\text {st }}, 2000$.

The statistical fee is $1 \%$ for all goods including exempt ones, with the exception of diplomatic privileges or imported goods under external financing.

The CSL rate is $1 \%$ on products not originating from the Union; allocated resources to the Union.

For temporary duties and taxes, there are essentially the degressive protection tax (TDP) and the conjuncture import tax (TCI).

Table 1. TDP application in three countries: Burkina Faso, Cote d'Ivoire and Senegal.

\begin{tabular}{cccc}
\hline Products & & Countries & Senegal \\
\hline Concentrated Milk & Burkina Faso & Cote d'Ivoire & - \\
Raw vegetable oils & - & - & - \\
Refined vegetable oils & $5 \%$ & $5 \%$ & - \\
Meat products & $5 \%$ & - & - \\
Sugar & - & $5 \%$ & $5 \%$ \\
Concentrated tomato & $5 \%$ & - & - \\
Cigarettes & - & $5 \%$ & - \\
Detergent powder & $5 \%$ & $5 \%$ & - \\
Matches & - & $5 \%$ & - \\
Jute bags & - & - & - \\
Polypropylene bags & $5 \%$ & - & - \\
Batteries & - & & - \\
\hline
\end{tabular}

Source: Commission of WAEMU, DPFDC, March 2006.

${ }^{8}$ Commission of the WAEMU, 1999. 
The TDP, ad valorem tax, temporary and degressive is created to offset the significant declines in tariff protection emanating from the establishment of the CET. It is collected only on industrial and agribusiness products imported from the rest of the world. The TDP, national implementation of community mechanism, applies only in States where an additional protection need arises. Its rates are $20 \%$ and $10 \%$ and its duration is 4 years.

The TDP expired since 2006, after several extensions from 2003. After ten (10) years of implementation, three major observations were made in the device. First, the requirements of the Industrial and Agricultural Policies of the Union, which were not adopted, had not been fully taken into account in its adoption. Then, the accompanying measures, which were to reinforce the temporary nature of decisions, by facilitating the adjustment of production devices, not only have not been identified, but also no restructuring program was applied while the device expires. For example, until its expiration in 2006, the TDP has hardly ever been applied in Senegal, although it underwent several extensions since 2003. Indeed, the TDP has hardly been applied to cigarettes before being suspended, these products are subject to a surcharge tax at the rate of $20 \%$, while the surcharge tax is not consistent with the architecture of the CET. In addition, the low infatuation among industrialists of this device could be related to its character that is limited over time, its complex approval procedures, its limited scope, and finally the calculation mode of the effective protection rate.

Finally, the option of a national implementation of the community measures, which themselves were a sprained knowingly accepted by the Union to the requirements of the common market, has limited the effectiveness. This resulted in a juxtaposition of national markets, and the community market was actually segmented.

The TCI (Table 2) is an ad valorem tax, intended to fight against the erratic fluctuations in world prices of certain products, and to counteract unfair import practices. It has a temporary nature in the sense that it will remain in force until the implementation of all WTO safeguard mechanisms. It is collected only on agricultural, agro-industrial, livestock and fishery products, excluding fish and fish-based products, upon their imports into the Union. It is a community tax of national implementation. Countries concerned for each product are specified by Commission Decision. Its rate is $10 \%$, but it can be collected according to the system of equalization.

Currently, it is worth noting that in Senegal, the TCI is applied to UHT milk, sweetened-condensed milk, nonsweetened-condensed milk, tomato paste, wheat flour, some fruit juice, at $10 \%$ rate. Regarding sugar, TCI is actually applied in the form of equalization. It is therefore no longer applied to refined vegetable oils.

However, it is worth noting that some activities may in no case be protected by the mechanism of the TCI as it currently operates. Indeed, one of the major criticisms of this mechanism relates to the fact that it does not protect industries not covered by the agricultural sector. The scope and the protective function of the TCI are limited by the fact that it remains a national application device. Thus, the non-application of TCI at community level does not discourage the importation of competing products in other member countries. This could lead to a possible lack of competitiveness within the community market of products subject to the TCI in a single Member State. Finally, TCI may be ineffective to protect industries against products for which the market value is very low or without world price (cases of chicken thighs among others).

Some sectors may in no case be protected by the mechanism of the TCI as it currently operates. Thus, important sectors such as poultry production suffer today from a lack of protection related to unfair competition. It is therefore necessary to think on the possibilities of the use of a specific mechanism of taxation, especially taxation in terms of weight. It seems worth pointing out that the EU uses this mechanism to fight against certain unfair trade practices. It takes the name of "fixed fee."

Table 2. TCI application in two countries: Cote d'Ivoire and Senegal.

\begin{tabular}{ccc}
\hline Products & Cote d'Ivoire & Senegal \\
\hline Wheat flour & $10 \%$ & $10 \%$ \\
Refined vegetable oils ${ }^{9}$ & $10 \%$ & $10 \%$ \\
Sugar & Equalization & Equalization \\
Concentrated tomato & $10 \%$ & $10 \%$ \\
\hline
\end{tabular}

Source: Commission of WAEMU, DPFDC, March 2006.

${ }^{9} \mathrm{TCI}$ is suspended for refined oils in Senegal. 
In the WAEMU-CET, categorization is based on:

- A main criterion: the degree of product processing;

- Ancillary criteria: the social character of the product and the concept of basic or equipment goods.

These criteria were guided by the desire to impart to finished products of the Union with adequate protection, and to contribute to the intensification of intra-community trade. They must also allow, first, the population of the Union to have, at lower cost social goods, and secondly, the WAEMU companies to acquire at lower cost, inputs unlikely to be produced in the union in the short and medium term.

The products appearing in the Tariff and Statistical Nomenclature are grouped into four (4) categories:

Category 0: Essential social goods.

Category 1: Basic goods, basic raw materials, equipment goods, specific inputs.

Category 2: Inputs and intermediate products.

Category 3: Final consumption goods.

The list of commodities of each category is decided through Council of Ministers regulation. Furthermore, imported products into Member States and from the rest of the world are compulsorily declared by application of this decision.

\section{Effects of Reforms on the Recovery in Senegal}

The first phase of the harmonization agenda concerned the internal indirect taxation because, on consumption, it is a complementary measure to the mechanisms of the Customs Union (CET and intra-community liberalization). The progressive establishment of the Customs Union will necessarily translate into revenue losses, if it is not accompanied by measures to improve the efficiency of domestic taxation. Thus, in order to speed up the convergence process, value added tax, excise duties, levies on petroleum products, the small business tax terms and the terms of administration of indirect taxes were selected.

The analysis of fiscal revenues over the period 1997-2005 (Table 3) captures the impact of the reforms initiated in 1996 on trade liberalization and the impact of the application of the CET and of harmonization of VAT regimes and of excise duties since 2000. The data used for this analysis came from the WAEMU Com- mission, based on a data collection through the circular mission of Member States.

Table 3 shows a steady growth of around $9.6 \%$ on average per year in the level of fiscal revenues of Senegal since the beginning of reforms. From CFA F 438.9 billion in 1998, fiscal revenues reached 919.5 billion in 2006.

This descriptive analysis of fiscal revenues shows a situation where reforms appear to play a major role in improving the level of tax collection. However, this analysis alone does not capture the impact of interdepen- dencies between Senegal and some other member countries of the Union.

The Directive No. 06/98/CM/UEMOA of December 22, 1998 relative to the Table of Financial Operations (TOFE), defines the classification of the major categories of taxes which States must comply with. Table 4 shows the evolution of elements of the structure of fiscal revenues in Senegal. Moreover, Table 5 shows the evolution of the weight of each element of the tariff structure in total fiscal revenues.

It appears from Table 4 that the structure of fiscal revenues is dominated in 2006 by taxes on foreign trade (377 billion CFA francs; 41\% of total revenues), followed by taxes on goods and services (286.7 billion; $31.2 \%$ of total revenues), taxes on income (210.2 billion; $22.9 \%$ of total revenues), property taxes (24.4 billion CFA francs; $2.7 \%$ of total revenue), stamp duties (11.7 billion CFA francs; $1.3 \%$ of total revenue) and the flat contribution paid by employers (9.5 billion CFA francs; $1.1 \%$ of total revenue). The other message arising from Table 4 is the decline in the share of taxes on foreign trade in total fiscal revenues. This induces some fiscal and customs translation, which if continued, could eventually help to break the country dependence on customs revenues.

\section{Determinants of Fiscal Pressure: A Literature Review}

The empirical literature on the determinants of fiscal pressure in Africa (see Ghura, $1998^{10}$; Stotsky et al. $1997^{11}$ for recent studies) showed that the rate of openness of the economy explains positively the variance of fiscal

\footnotetext{
${ }^{10}$ Ghura, D. (1998) Tax revenue in Sub-Saharan Africa: Effects of economic policy and corruption. IMF Working Paper, No. 98/135, 25 p [4].

${ }^{11}$ Stotsky, J.B. and Woldemariam, A. (1997) Tax effort in sub-Saharan Africa. IMF Working Paper, WP/97/107, September, 57 p [5].
} 
Table 3. Evolution of fiscal revenue in Senegal (billions of current CFA francs).

\begin{tabular}{ccccccccccccccccccccccccccc}
\hline & $\begin{array}{c}\text { Moy } \\
\mathbf{8 6 - 9 6}\end{array}$ & $\begin{array}{c}\text { Moy } \\
\mathbf{9 7 - 0 6}\end{array}$ & $\begin{array}{c}\text { Moy } \\
\mathbf{0 7 - 1 4}\end{array}$ & $\mathbf{1 9 9 7}$ & $\mathbf{1 9 9 8}$ & $\mathbf{1 9 9 9}$ & $\mathbf{2 0 0 0}$ & $\mathbf{2 0 0 1}$ & $\mathbf{2 0 0 2}$ & $\mathbf{2 0 0 3}$ & $\mathbf{2 0 0 4}$ & $\mathbf{2 0 0 5}$ & $\mathbf{2 0 0 6}$ & $\mathbf{2 0 0 7}$ & $\mathbf{2 0 0 8}$ & $\mathbf{2 0 0 9}$ & $\mathbf{2 0 1 0}$ & $\mathbf{2 0 1 1}$ & $\mathbf{2 0 1 2}$ & $\mathbf{2 0 1 3}$ & $\mathbf{2 0 1 4}$ & \\
\hline $\begin{array}{c}\text { Fiscal } \\
\text { revenues }\end{array}$ & 246.3 & 626 & 1234.0 & 401.1 & 438.9 & 491.1 & 537.1 & 576.9 & 629.2 & 676.9 & 738.5 & 850.7 & 921.9 & 1041 & 1087 & 1085 & 1195 & 1287 & 1352 & 1343 & 1483 & \\
$\begin{array}{c}\text { Growth of } \\
\text { fiscal } \\
\text { revenues }\end{array}$ & $7.70 \%$ & $9.60 \%$ & $6.22 \%$ & $8.60 \%$ & $9.43 \%$ & $11.91 \%$ & $9.36 \%$ & $7.41 \%$ & $9.06 \%$ & $7.59 \%$ & $9.09 \%$ & $15.19 \%$ & $8.37 \%$ & $12.97 \%$ & $4.39 \%$ & $-0.24 \%$ & $10.16 \%$ & $7.71 \%$ & $5.04 \%$ & $-0.66 \%$ & $10.41 \%$ \\
\hline
\end{tabular}

Source: DPEE, 2015 and author calculations.

Table 4. Evolution of the structure of fiscal revenues of Senegal (in billions of francs CFA currents).

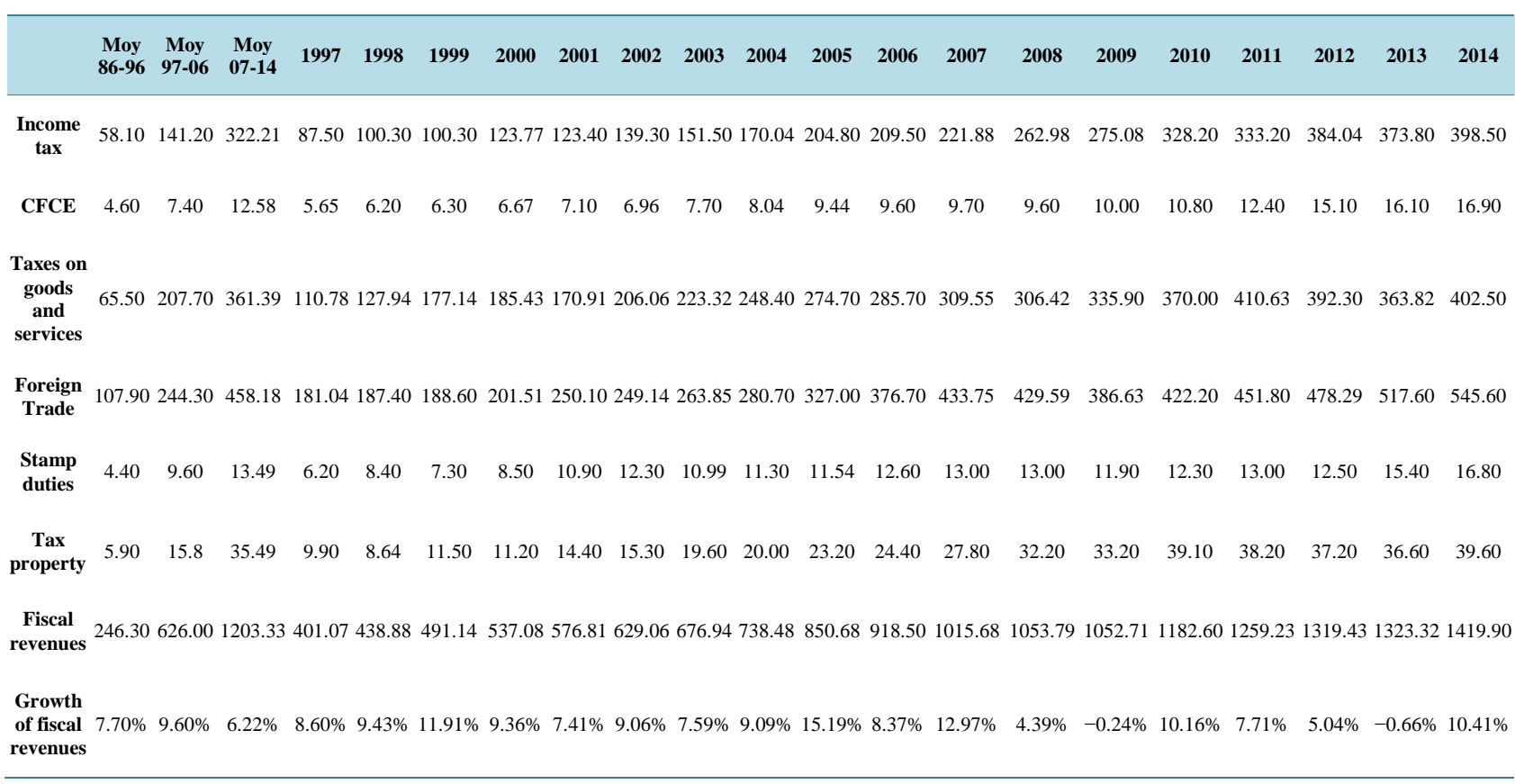

Source: DPEE, 2015 and author calculations.

Table 5. Evolution of the weight of each element of the tariff structure in total fiscal revenues.

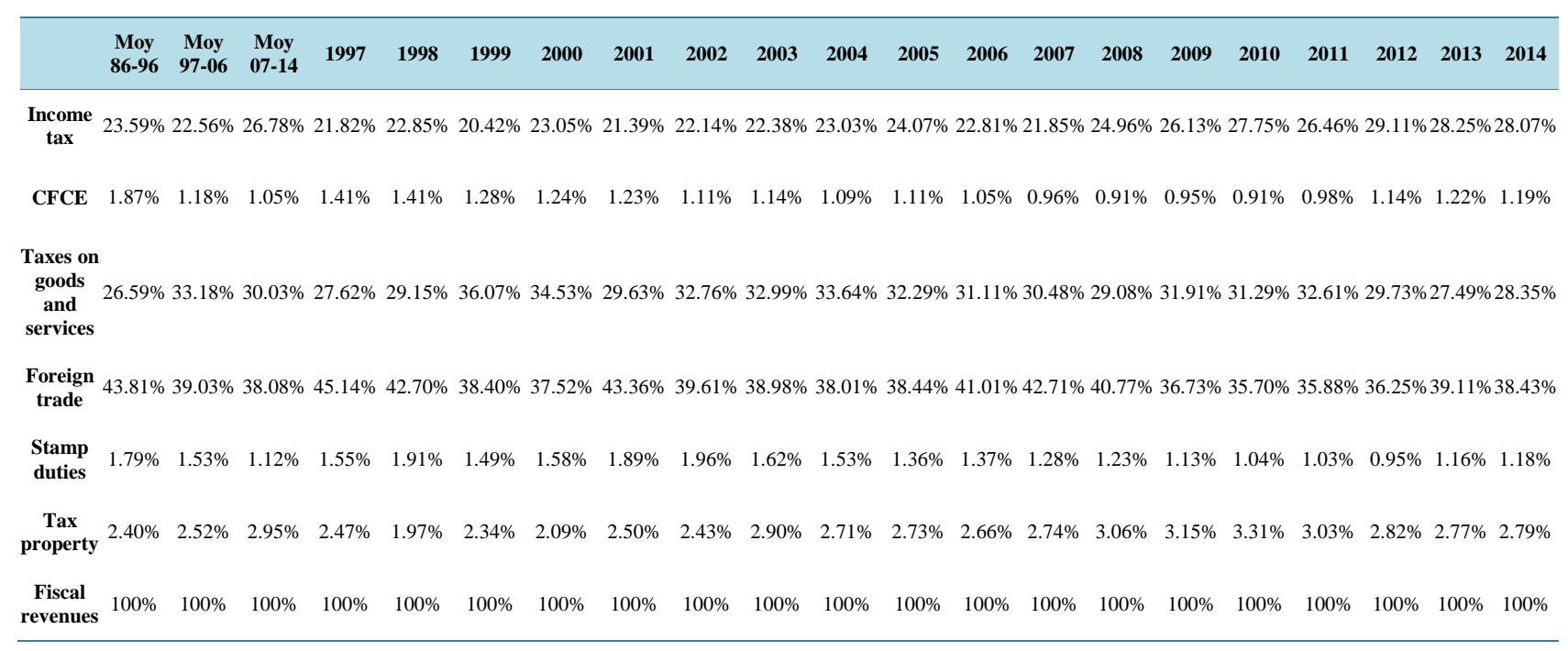

Source: DPEE, 2015 and author calculations. 
pressure rate between countries and over time (panel data econometrics). For Ghura (1998) [4], the degree of openness is the variable that has the highest explanatory power over a period between 1985 and 1996 and on 39 African countries. We deduce then that fiscal revenues of African countries remained very sensitive to taxes on foreign trade.

A vertical externality occurs when the fiscal choice of a level of government affects the budget of another level of government (Boadway and Vigneault, 1996) ${ }^{12}$. That is the case when taxes collected by a government level are eligible for a credit or a fiscal deduction for another level of government, or when two or more levels of government grant fiscal exemptions, or when several public authorities ladder taxing the same taxable base; an idea found under the term "concurrent taxation" or "tax base sharing” in North American literature.

The studies of Flowers (1988) ${ }^{13}$ and Johnson (1988) ${ }^{14}$ provided the agenda of the issue of tax overlay.

Keen (1998) [9], Esteller-Morer and Solé-Ollé (2001) ${ }^{15}$ and Keen and Kotsogiannis (2002) [11] showed that this issue is far from being solved empirically. An increase in the collection level of national government (or federal government) has an ambiguous effect on the taxation rate for sub-state communities.

In an analysis of welfare, Jones and Morrow-Jones $(1984)^{16}$ built a one-region model. Their aim is to understand the influence of local taxes and their redistribution on the implantation of workers, that is to say, the impact of local taxation in demographic terms. They concluded that the distribution of income from fiscal revenues has a very large impact on the population.

Looking directly at economic activity, and leaving aside population, supposed immobile, Mutti, Morgan and Partridge (1989) ${ }^{17}$ ended up with the same conclusion, namely that property taxes and taxes on households are preferable to business taxes. They drew these results from simulations of various fiscal policies based on a model of six regions calibrated on the US. Their findings revealed also a high negative elasticity of economic activity on local tax rates on business.

Studies on the optimal levels of indirect taxes that resulted from the article of Ramsey (1927) ${ }^{18}$ consider that indirect taxes are fully paid by consumers. This, particularly because of the practical form of such taxes where the impression is given that it is consumers that bear the burden of tax. Ramsey (1927) [14] computed the optimal rates of indirect taxes in order to maximize the utility of consumers, while collecting given fiscal revenues. His recommendation is to tax more goods for which demand is relatively inelastic, and less those for which demand would fall if they were more taxed. Despite these technical characteristics of the empirical analysis, all studies show that the differentiated taxation rates are optimal. For Deaton $1981^{19}$, this result holds regardless of either the context of hypothesis (representative agent or multiple agents) or the type of economy concerned. In addition, the multi-agent framework tends to accentuate the differentiation of tax rates as the "degree of aversion to inequality" is growing in the social utility function.

Base on estimates made for India, Srinivasan $(1989)^{20}$ showed that the optimal tax rate can become negative (subsidy) for basic goods when the degree of aversion to inequality is high. Since it seems optimal and particularly fair to apply differential rates to the taxation of goods, then we may question the appropriateness of reforms in least developed countries (LDCs). Reforms of indirect taxation are in fact generally consisted of applying a uniform rate of tax on value added (in maximum two rates) and to exempt basic goods and social services (Abed, $1998^{21}$, Tanzi and Zee, $2000^{22}$ ).

\footnotetext{
${ }^{12}$ Boadway, R. et VIGNEAULT, M. (1996) The interaction of federal and provincial taxes on Businesses. Technical Committee on Business Taxation, Working Paper 96-11, Department of Finance, Ottawa, December 1996, 29 p [6].

${ }^{13}$ Flowers, M.R. (1988) Shared tax sources in Leviathan model of federalism. Public Finance Quarterly, Vol. 16, pp. 67-77 [7].

${ }^{14}$ Johnson, W. (1988) Income redistribution in a federal system. American Economic Review, Vol. 78 (3), pp. 29-46 [8].

${ }^{15}$ Esteller-Moré, A. et Sollé-Ollé, A. (2001) Vertical income tax externalities and fiscal interdependence: Evidence from the US. Regional Science and Urban Economics, Vol. 31, pp. 247-272 [10].

${ }^{16}$ Jones, D. and Morrow-Jones, C. (1984) Local taxation and the consequences of revenue distribution patterns. Regional Science and Urban Economics, 14, 63-69 [12]

${ }^{17}$ Mutti, J., Morgan, W. and Partridge, M. (1989) The incidence of regional taxes in a general equilibrium framework. Journal of Public Economics, 39, 83-107 [13].

${ }^{18}$ Ramsey (1927) A contribution to the theory of taxation. Economic Journal, Vol. 37, No. 1, pp. 47-61 [14].

${ }^{19}$ Deaton, A.S. (1981) Optimal taxes and the structure of preferences. Econometrica, Vol. 49, No. 5, pp. 1245-1260 [15].

${ }^{20}$ Srinivasan, P.V. (1989) Redistributive impact of “optimal” commodity taxes. Evidence from Indian data. Economics Letters, Vol. 30, pp. 385-388 [16].

${ }^{21}$ Abed, G.T. (1998) Fiscal reform in Low-Income Countries: Experience under IMF supported programs. IMF Occasional paper No. 160, $90 \mathrm{p}[17]$.

${ }^{22}$ Tanzi, V. et Zee, H.H. (2000) Tax policy for emerging market: developing countries. IMF Working Paper No. WP/00/35, 34 p [18].
} 
Developing the lemma of Diamond and Mirrlees (1971) $)^{23}$ in an open economy setting, Dixit $(1985)^{24}$ showed that the dead weight caused by customs tariff is higher than that driven by a tax on domestic consumption. The application of customs tariffs is suboptimal, even in a framework of "second best" equilibrium.

Extending this demonstration on the optimal taxation models in open economy, Michael et al. $(1993,1994)^{25}$, Keen and Ligthart (1999) ${ }^{26}$ showed that a decrease in customs tariffs, which would be offset in fiscal revenues by increasing domestic indirect taxes, would have the effect of reducing the "dead weight", eliminating dis- tortions on supply. The theoretical justification of "fiscal and customs transition" is then found. These results hold only under the assumption of perfect competition and of absence of negative externalities resulting from international trade. Corden (1984) ${ }^{27}$ showed that by taking into account market imperfections, taxation of international trade can provide an optimal solution of "third best", particularly in the context of the theory of "infant industries".

\section{Impact of WAEMU Reforms on Senegalese Economy: Application of a Simulation Model of the CET}

\subsection{Evolution of Fiscal Revenues}

The evolution of the structure of fiscal revenues is presented in Table 6 and Table 7. It appears that the share of income taxes and forfeit contribution paid by employers (CFCE) in total fiscal revenues is relatively stable. It passed on average from $24.6 \%$ during the period $95 / 99$ to $23.2 \%$ over the period 2000/2005. The share of taxes on goods and services has considerably increased from $25 \%$ to $32.2 \%$. However, the relative share of taxes on foreign trade has decreased from $44.7 \%$ in the period $95 / 99$ to $40.8 \%$ over the period 2000/2005.

The fiscal reforms implemented in the context of WAEMU (lower customs duties with the application of a CET in particular, introduction of a single VAT) creates a fiscal and customs translation with an increase in the relative share of domestic taxes at the expense of the entry duties, even if the latter have followed an upward trend.

It should be noted an increase in the relative share of import VAT in total fiscal revenues, an increase from 12.8 in 2001 to $19.7 \%$ in 2005.

\subsection{Nomenclature of Fiscal Revenues and Their Treatment in the Model}

The nomenclature of fiscal revenues is based on that of the table of financial operations (TOFE). The classification of fiscal revenues was made on the basis of their status as endogenous or exogenous variable in the model and data availability over a relatively long period ${ }^{28}$. Thus we can distinguish income taxes, taxes on goods and services, stamp duties, taxes on foreign trade and property taxes.

Income taxes (IR) include:

$>$ Income Tax of Moral Persons (IRPM), which includes taxes on Industrial and Commercial Profits (BIC), tax on non-commercial profits (BNC) and corporation tax (IS);

$>$ Tax on personal income (IRPP), which corresponds to the single tax;

$>$ The lump sum contribution paid by employers (CFCE);

$>$ Other Income Taxes (AIR), which include taxes on Services (ITS), Tax on Income of Capital Furniture (IRCM), tax on property income (IRF), Taxes on Property Rents and the General Tax on Income (IGE).

$>$ If the income tax of moral persons, tax on income of physical persons and the lump sum contribution paid by employers are subject to econometric estimations, the remaining taxes on revenue are exogenous.

\footnotetext{
${ }^{23}$ Diamond, P.A. et Mirrlees, J.A. (1971) Optimal taxation and public production 1: Production efficiency and 2: tax rules. American Economic Review, Vol. 61, pp. 8-27 et pp. 261-278 [19].

${ }^{24}$ Dixit, A. (1985) Tax policy in open economies. In: Auerbach, A.J. et Feldsetin, M., Eds., Handbook of Public Economics, Vol. I [20].

${ }^{25}$ Michael, M.S., Hazipanayotou, P. and Miller, S.M. (1993) Integrated reform of tariffs and consumption taxes. Journal of Public Economics Vol. 52, pp. 417-28 [21].

Michael, M.S., Hazipanayotou, P. and Miller, S.M. (1994) Win-win indirect tax reform—A modest proposal. Economics Letters, Vol. 44, pp 147-151 [22].

${ }^{26}$ Keen, M. et Lightart, J.E. (1999) Coordinating tariff reduction and domestic tax reform. IMF Working Paper, No. WP/99/93, July, 20 pages [23].

${ }^{27}$ Corden (1984) The normative theory of international trade. In: Jones, R.W. et Kenen, P.B., Eds., Handbook of International Economics, Vol. I [24].

${ }^{28}$ Econometric estimates require data availability over a period covering at least 15 - 20 years. Compliance with this requirement was not possible to isolate the VAT on oil products and domestic VAT.
} 
Table 6. Evolution of the structure of fiscal revenues (\% of total).

\begin{tabular}{|c|c|c|c|c|c|c|c|c|c|c|c|}
\hline & 1995 & 1996 & 1997 & 1998 & 1999 & 2000 & 2001 & 2002 & 2003 & 2004 & 2005 \\
\hline Income taxes & 22.7 & 24.4 & 25.2 & 22.1 & 22.8 & 21.4 & 21.8 & 22.8 & 20.6 & 22.6 & 21.9 \\
\hline BIC. BNC. IS & 5.1 & 7.1 & 5.1 & 3.8 & 6.3 & 6.2 & 7.2 & 7.6 & 8 & 9.1 & 8.7 \\
\hline ITS & 0.4 & 0 & 0 & 0 & 0 & 0 & 0 & 0 & 0 & 0 & 0 \\
\hline IRCM & 3 & 1.9 & 1.9 & 2.4 & 1.9 & 1.7 & 1.2 & 1.5 & 1.4 & 1.9 & 2.1 \\
\hline IRF & 0.1 & 0.4 & 0.1 & 0 & 0.1 & 0.1 & 0.1 & 0 & 0 & 0 & 0 \\
\hline Taxes/p.v. immob. & 0 & 0.1 & 0.1 & 0.2 & 0.1 & 0.1 & 0.1 & 0.1 & 0.1 & 0.1 & 0.2 \\
\hline IGR & 0.5 & 1.1 & 3.1 & 2.8 & 1.1 & 0.9 & 0.4 & 0.5 & 0.1 & 0 & 0 \\
\hline Single tax & 13.6 & 13.8 & 14.9 & 12.8 & 13.4 & 12.3 & 12.7 & 13.1 & 11 & 11.6 & 10.9 \\
\hline CFCE & 1.7 & 1.7 & 1.8 & 1.5 & 1.4 & 1.5 & 1.4 & 1.4 & 1.2 & 1.2 & 1.2 \\
\hline Income taxes and CFCE & 24.4 & 26 & 27 & 23.6 & 21.9 & 22.9 & 23.2 & 24.2 & 21.9 & 23.9 & 23.1 \\
\hline Taxes on goods and services & 25 & 23.3 & 25.3 & 25.8 & 25.3 & 25.6 & 27.6 & 29.1 & 36.6 & 39.8 & 34.4 \\
\hline VAT. TPS. TE. TOB & 20.9 & 19.6 & 21.4 & 22.5 & 22.3 & 23 & 25.2 & 22.8 & 24 & 27.3 & 23.1 \\
\hline Of which equalization tax & 0 & 0 & 0 & 0 & 0 & 0 & 1.2 & 1.2 & 1.1 & 1.1 & 1.5 \\
\hline Of which TOB & 0 & 0 & 0 & 0 & 0 & 0 & 1.6 & 1.6 & 1.6 & 1.7 & 2 \\
\hline Of which oil VAT & 0 & 0 & 0 & 6.5 & 5 & 4.3 & 4.7 & 4.9 & 4.1 & 5.3 & 3.6 \\
\hline Tax on consumption & 3 & 2.6 & 2.8 & 2.4 & 2 & 1.7 & 1.5 & 5.5 & 11.8 & 11.7 & 10.4 \\
\hline Of which oil & 0 & 0 & 0 & 0 & 0 & 0 & 0 & 4 & 10.2 & 10.2 & 8.6 \\
\hline Insurance tax & 0.4 & 0.4 & 0.5 & 0.3 & 0.4 & 0.4 & 0.4 & 0.4 & 0.4 & 0.4 & 0.4 \\
\hline Tax on vehicle & 0.6 & 0.6 & 0.7 & 0.6 & 0.6 & 0.5 & 0.5 & 0.4 & 0.4 & 0.4 & 0.5 \\
\hline Stamp duties & 2.3 & 2.9 & 2.4 & 2 & 1.6 & 1.6 & 1.6 & 1.9 & 1.5 & 1.6 & 1.9 \\
\hline Foreign trade & 41.4 & 45.1 & 43.3 & 46.3 & 47.1 & 48.3 & 45.1 & 42.8 & 37.7 & 32.6 & 38.1 \\
\hline VAT on import & 0 & 0 & 0 & 0 & 0 & 0 & 12.8 & 15 & 14 & 16.9 & 19.7 \\
\hline Of which oil & 0 & 0 & 0 & 0 & 0 & 0 & 0.3 & 0.3 & 0.7 & 2.1 & 4.2 \\
\hline Entry duties & 0 & 0 & 0 & 0 & 0 & 0 & 32.3 & 27.8 & 23.7 & 15.7 & 18.4 \\
\hline \multirow[t]{2}{*}{ Of which oil } & 0 & 0 & 0 & 0 & 0 & 0 & 5.2 & 2.6 & 2.1 & 2.1 & 0.8 \\
\hline & 0 & 0 & 0 & 0 & 0 & 0 & 0 & 0 & 0 & 0 & 0 \\
\hline Tax on property & 6.9 & 2.7 & 2 & 2.4 & 1.8 & 1.6 & 2.5 & 2 & 2.3 & 2.1 & 2.5 \\
\hline Total & 100 & 100 & 100 & 100 & 100 & 100 & 100 & 100 & 100 & 100 & 100 \\
\hline
\end{tabular}

Source: Republic of Senegal, General Directorate of Taxes and Domains, 2007.

Table 7. Average share of different categories of tax in total fiscal revenues.

\begin{tabular}{ccc}
\hline & $1995 / 1999$ & $2000 / 2005$ \\
\hline Income taxes and CFCE & 24.6 & 23.2 \\
Taxes on goods and services & 24.9 & 32.2 \\
Stamp duties & 2.2 & 1.7 \\
Foreign trade & 44.7 & 40.8 \\
Tax on property & 3.1 & 2.2 \\
\hline
\end{tabular}

Source: Republic of Senegal, General Directorate of Taxes and Domains, 2007 
Taxes on Goods and Services (TXBS) consist of the following:

- Value added tax (VAT), which includes not only VAT but also tax on services, equalization tax (TE) and tax on banking operations;

- Taxes on consumption (TAXCONS);

- Other taxes (ATAX) that include insurance taxes and taxes on vehicles.

- VAT and tax on consumption are specified as a behavioral equation, while other taxes are exogenous.

Stamp duties have exogenous status in the model. Taxes on foreign trade (ICEXT) include customs duties and import VAT. They are estimated in the econometric model. Taxes on property (IPR) include registration fees and mortgage fees. This tax category is exogenous in the model.

\subsection{Structure and Simulation of the Model}

The model that was developed allow to simulate the impact of the CET on fiscal revenues and prices. The analysis of the impact of the CET on competitiveness has been carried out outside of the model. This model includes a set of behavioral equations and accounting identities.

The behavioral equations describe the following fiscal revenues:

$>$ Tax on income of moral persons (IRPM);

$>$ Tax on personal income (IRPP);

$>$ The fixed contribution payable by employers (CFCE);

$>$ VAT;

$>$ Taxes on consumption;

$>$ Taxes on foreign trade.

The behavioral equations were estimated over the period from 1986 to 2004.

Taxes on income of moral persons include BIC, BNC and IS. The chosen replacement taxable base is the gross operating surplus of enterprises. To the extent that this replacement base is wider than the actual base, the equation was estimated iteratively until the tax rate is close to the official rate of $33 \%$. The following results were obtained:

$$
\operatorname{IRPM}_{\mathrm{t}}=0.330018 *\left[0.1225 * \mathrm{EBE}_{\mathrm{t}-1}\right]-21.47121
$$

EBE: gross operating surplus of enterprises in the modern sector.

These results indicate that the apparent tax rate of the IRPM is around 33\% while the replacement base represents $12.25 \%$ of EBE of the previous year of the modern sector. The constant represents the surtax or tax on income of moral persons paid in the case the operating loss has a negative sign. This suggests that this surcharge is poorly collected.

The alternative taxable base on personal income is represented by payroll of the entire modern sector, that is to say the salaries paid by enterprises and administration. The findings of the estimations of the IRPP reveal that the apparent tax rate amounts to $11.4 \%$. Moreover, this tax was positively affected by the economic conditions of 1992 and negatively by those of 1990. The results of the estimations are:

$$
\operatorname{IRPP}_{\mathrm{t}}=0.114540 *\left(\mathrm{SALSM}_{\mathrm{t}}\right)+5.327835 * \operatorname{ID}_{1992-16.76243 * \operatorname{ID} 1990}
$$

SALSM: wages paid by the modern sector;

ID: is a dummy variable.

The replacement base for the flat-rate contribution to be borne by employers (CFCE) is represented by payroll of modern merchant sector that is to say apart from administrations. The estimation results indicate that the apparent tax rate CFCE amounts to $0.92 \%$.

$$
\mathrm{CFCE}_{\mathrm{t}}=0.009258 * \mathrm{SALSMM}_{\mathrm{t}}+3.439964
$$

SALSMM: wages paid by the merchant modern sector that is to say apart from administrations.

The VAT replacement taxable base consists of the gross domestic product (GDP) at factor costs of non- primary sector since the activities of primary sector escape this tax. The results of the estimation are as follows:

$$
\text { VAT }_{\mathrm{t}}=0.043622 *\left(\mathrm{PIBCF}_{\mathrm{t}}-\text { PIBPRIM }_{\mathrm{t}}\right)-16.36635 * \operatorname{ID} 1994+27.30815 * \operatorname{ID2} 2000
$$

PIBCF: GDP at factor costs; 
PIBPRIM: primary sector GDP;

ID: dummy variable.

These results indicate that the apparent VAT rate is $4.4 \%$ and the return of this tax was negatively impacted by the 1994 economic situation and positively with that of 2000 .

The consumption taxes replacement base is represented by the final consumption of households. The estimation results show that the apparent rate of consumption taxes amounted to $2.9 \%$. The negative sign of the constant indicates that the level of collection of this tax is lower than the tax potential:

$$
\text { TAXCONS }_{\mathrm{t}}=0.029571 * \mathrm{CFM}_{\mathrm{t}}-42.24058
$$

CFM: Household final consumption (in value).

The taxable base of foreign trade that was retained is measured by imports of goods and services excluding capital goods since the latter are subject to low customs duty, even exemptions. The results show that the apparent rate of taxes on foreign trade is about $18 \%$.

$$
\operatorname{ICEXT}_{\mathrm{t}}=0.179665 *\left(\mathrm{MBS}_{\mathrm{t}}-\mathrm{MEQ}_{\mathrm{t}}\right)+39.03558 * \mathrm{ID} 1992+37.40688 * \mathrm{ID} 1997
$$

MBS: imports of goods and services (in value);

MEQ: imports of capital goods (in value).

The prices that were modeled include consumer prices and prices in the manufacturing sector.

The consumer price excluding taxes is explained by the following factors: unit labor cost (cost inflation), imported inflation approximated by the deflator of imports.

$$
\log \mathrm{PCHT}=-0.65+0.47 * \operatorname{LogPCHT}(-1)+0.043 * \operatorname{LogCSU}+0.12 * \log \mathrm{PM}
$$

where:

PCHT: Consumer prices excluding tax;

CSU: Unit labor cost;

PM: deflator of imports.

The unit labor cost is measured as follows:

$$
\mathrm{CSU}=\mathrm{SALSM} / \mathrm{VASM}
$$

SALSM: wages paid by the modern sector;

VASM: added value in the modern sector;

The price index excluding tax is obtained through a correction of indirect taxation especially VAT.

$$
\text { PCHT }=\text { PCTTC } /(1+\text { TFI }) / 100
$$

PCTTC: Consumer prices including all taxes;

TFI: indirect tax rates.

Manufacturing sector prices are expected to grow with an industry indicator of competitiveness and the capacity utilization rate of production units

$$
\log \text { PSM }=0.29+0.86 * \operatorname{LogPSM}(-1)+0.03 * \log \text { COMP }+0.09 * \log \text { TUC }
$$

where

PSM: price of manufacturing sector;

COMP: manufacturing sector competitiveness indicator;

TUC: capacity utilization rate in the manufacturing sector.

The competitiveness indicator is measured by the ratio per capita wage ratio over manufacturing sector productivity, while the capacity utilization rate is estimated by extrapolation method of summits.

The price index of the manufacturing sector excluding taxes is also obtained by a correction of the tax

$$
\text { PSMHT = PSMFTTC } /(1+\text { TTVA }) / 100
$$

PSMTTC: price of manufacturing sector, all taxes included;

TVA: VAT rate.

Accounting equations are equations of definition or of equilibrium which include the following variables:

- Total income taxes; 
- Total taxes on goods and services;

- Total fiscal revenues.

Total income taxes are the sum of income tax of moral persons, tax on personal income, flat-rate contribution paid by employers and other income taxes:

$$
\mathrm{IR}_{\mathrm{t}}=\mathrm{IRPM}_{\mathrm{t}}+\mathrm{IRPP}_{\mathrm{t}}+\mathrm{CFCE}_{\mathrm{t}}+\mathrm{AIR}_{\mathrm{t}}
$$

IR: total income taxes.

Total taxes on goods and services are equal to the sum of VAT, consumption taxes and other taxes:

$$
\mathrm{TXBS}_{\mathrm{t}}=\mathrm{TVA}_{\mathrm{t}}+\mathrm{TAXCONS}_{\mathrm{t}}+\mathrm{ATAX}_{\mathrm{t}}
$$

TXBS: total taxes.

The total fiscal revenue is equal to the sum of income taxes, taxes on goods and services, stamp duties, taxes on foreign trade and property taxes:

$$
\mathrm{RF}_{\mathrm{t}}=\mathrm{IR}_{\mathrm{t}}+\mathrm{TAXBS}_{\mathrm{t}}+\mathrm{DT}_{\mathrm{t}}+\mathrm{ICEXT}_{\mathrm{t}}+\mathrm{IPR}_{\mathrm{t}}
$$

RF: total tax revenues;

DT: stamp duties;

IPR: Property taxes.

The model presented below was used to simulate the impact of the CET and VAT on tax revenues and prices.

a) Specification of variants

The impact of tax reforms implemented (CET and a new VAT regime) was traced through the simulation of the variation in the rate of customs duty, VAT rates and tax rates on consumption. The CET being applied since 2000, the change in the customs duty rate was estimated by comparing the average of the apparent rate of customs duty between 1995-1999 and 2000-2004. It is thus obvious that the apparent rate fell of about $12.75 \%$.

Regarding VAT, it has been applied from the end of the third quarter of 2001. The change in VAT and consumption taxes rates was estimated by comparing average apparent rate between 1996-2000 and 2001-2006. The results indicate that the apparent rate of VAT and consumption taxes increased by $4.52 \%$ and $72.62 \%$ respectively.

Simulations are based on the estimated variation of apparent rates of customs duty, VAT and consumption taxes. The impact of the reforms is measured by the difference between the central account and the values obtained resulting from the modification of the apparent rate.

\section{b) Simulation of fiscal revenues}

The results of the impact of changes in rates of customs duty, VAT and consumption taxes are presented in Table 8. It thus appears that the application of the new tax system with a single VAT rate of $18 \%$ had positive impact on fiscal revenues. Compared to an unchanged fiscal legislation, fiscal revenues increased by nearly 105 billion in 2007. The estimated impact has a growing effect and stood at 131.66 billion in 2013.

The results also indicate that declining tariff rates had a depressive effect on fiscal revenues. The estimated decline in fiscal revenues amounted to nearly 41 billion in 2007 and to 51.75 billion in 2013. However, overall, the positive effect of VAT and consumption taxes outweighs the depressive effect of lower tariffs on fiscal revenues. Thus, the overall impact of the reforms on total fiscal revenues is positive and amounts to 63.78 billion in 2007 against 79.9 billion in 2013.

\section{c) Price Simulations}

The impact of the reform of indirect taxes on consumer prices and prices in the manufacturing sector is traced in Table 9. The consumer prices inclusive of all taxes are obtained by adding to the price excluding tax the

\begin{tabular}{|c|c|c|c|c|c|c|c|}
\hline & 2007 & 2008 & 2009 & 2010 & 2011 & 2012 & 2013 \\
\hline Impact of VAT and consumption taxes & 104.70 & 109.19 & 113.69 & 118.18 & 122.67 & 127.16 & 131.66 \\
\hline Impact of customs duties & -40.92 & -42.72 & -44.53 & -46.34 & -48.14 & -49.95 & -51.75 \\
\hline Impact of total reforms & 63.78 & 66.47 & 69.16 & 71.84 & 74.53 & 77.22 & 79.90 \\
\hline
\end{tabular}

Table 8. Impact of changes in customs duties, VAT and consumption taxes in total fiscal revenues (Unit: billion current CFA). 
Table 9. Impact of the reform of indirect taxes on consumer and manufacturing sector prices.

\begin{tabular}{lcc}
\hline Years & PCTTC & PSMTTC (\%) \\
2002 & 5.70 & 6.09 \\
2003 & 5.48 & 5.65 \\
2004 & 5.34 & 5.89 \\
2005 & 5.20 & 5.68 \\
2006 & 5.46 & 6.00 \\
2007 & 5.71 & 6.19 \\
2008 & 5.93 & 6.30 \\
2009 & 6.15 & 6.37 \\
2010 & 6.35 & 6.43 \\
2011 & 6.55 & 6.48 \\
2012 & 6.74 & 6.52 \\
2013 & 6.92 & 6.56 \\
\hline
\end{tabular}

apparent consumption taxes. As for prices of manufacturing tax inclusive of all taxes, the tax rate that has been applied is the apparent rate of VAT.

It thus appears that the increase in indirect taxation subsequent to the reforms of WAEMU has generated inflation. Compared to the baseline (unchanged fiscal legislation), consumer price indices and manufacturing sector price indices grew faster. This upward effect increases over time. Regarding consumer prices, the estimated gap is of $5.70 \%$ in 2002, 5.71\% in 2007 and $6.92 \%$ in 2013. For prices of manufacturing sector, the gaps are more important because they amounted to $6.09 \%$ in $2002,6.19 \%$ in 2007 and $6.56 \%$ in 2013.

\section{Conclusions and Recommendations}

Fiscal reforms implemented by the WAEMU countries in the late 90s are characterized by tariff reductions, which led to a sharp decline in the average rate of customs duties. They also led to a change in the structure of fiscal revenues. They allow achieving a fiscal and customs swith, the weight of domestic taxes being higher than the import duties. However, the share of fiscal revenues between direct taxes and indirect taxes is relatively stable, the latter still represents almost three quarters of total fiscal revenues. The Senegalese fiscal system remains regressive and inequitable. To reconcile the financial economic and social functions of tax, it is important to implement the following measures:

> Improve recovery performance of direct taxes through a series of actions (increase of human and material resources of the fiscal administration, increase of the taxable base through tax compliance promotion strategy that goes through improving the quality of public service and the gradual formalization of the informal sector in particular);

$>$ Use of other trade policy instruments (non-tariff measures such as standards, strengthening the repressive arsenal against fraud, counterfeiting and piracy) to safeguard the national economy.

> Among the factors explaining the good behavior of customs revenues, we can also note the entry into force on July 1 $1^{\text {st }}, 2001$ of the Agreement on Customs Valuation of the World Trade Organization (WTO) and the Program of Verification of Imports (PVI) which contributed to a better control of the taxable base. On top on this, we have added the atypical behavior of petroleum products which because of the rise of oil prices which began since 2004, combined with the difficulties encountered by the African Refining Company (SAR), has favored the importation of finished products, and therefore more heavily taxed to the detriment of crude oil. A strong conclusion from this study is that the WAEMU-CET, although it has had some impacts on the re- 
covery and prices, has not significantly influenced the international competitiveness of Senegal. However, for a number of products such as subsidized products or others such as milk, chicken, textiles, sugar, the CET appears to induce unfair competition or because the taxable bases at customs are biased (case of textiles), or because imported goods compete unfairly local production (case of chicken).

This makes very relevant discussion on the desirability of the establishment of a fifth band in the customs nomenclature for the ECOWAS-CET. It seems premature, from our point of view to set the rate for the fifth band arbitrarily. It is necessarily to conduct relevant investigations to ensure that this rate produces the desired protection on targeted sectors and that such protection is neither redundant nor insufficient.

Our methodology which is based on a partial equilibrium approach has allowed us to simulate, ceteris paribus, likely impact of CET on critical macroeconomic variables. To have a broader understanding of such reform on overall economic structure, a general equilibrium modeling would be worth considering.

\section{References}

[1] Acte Additionnel No. 04/96 of May 10, 1996.

[2] Acte additionnel No. 01/97 of June 23, 1997.

[3] Acte additionnel No. 04/98 of December 30, 1998.

[4] Ghura, D. (1998) Tax Revenue in Sub-Saharan Africa: Effects of Economic Policy and Corruption. IMF Working Paper No. 98/135, 25 p.

[5] Stotsky, J.B. and Woldemariam, A. (1997) Tax Effort in Sub-Saharan Africa. IMF Working Paper, WP/97/107, 57 p.

[6] Boadway, R. and Vigneault, M. (1996) The Interaction of Federal and Provincial Taxes on Businesses. Technical Committee on Business Taxation, Working Paper 96-11, Department of Finance, Ottawa, 29 p.

[7] Flowers, M.R. (1988) Shared Tax Sources in Leviathan Model of Federalism. Public Finance Quarterly, $16,67-77$.

[8] Johnson, W. (1988) Income Redistribution in a Federal System. American Economic Review, 78, 29-46.

[9] Keen, M. (1998) Vertical Tax Externalities in the Theory of Fiscal Federalism. International Monetary Fund Staff Papers, 45, 454-485. http://dx.doi.org/10.2307/3867412

[10] Esteller-Moré, A. and Sollé-Ollé, A. (2001) Vertical Income Tax Externalities and Fiscal Interdependence: Evidence from the US. Regional Science and Urban Economics, 31, 247-272. http://dx.doi.org/10.1016/S0166-0462(00)00060-0

[11] Keen, M. and Kotsogiannis, C. (2002) Does Federalism Leads to Excessive High Taxes? American Economic Review, 92, 363-370.

[12] Jones, D. and Morrow-Jones, C. (1984) Local Taxation and the Consequences of Revenue Distribution Patterns. Regional Science and Urban Economics, 14, 63-69. http://dx.doi.org/10.1016/0166-0462(84)90043-7

[13] Mutti, J., Morgan, W. and Partridge, M. (1989) The Incidence of Regional Taxes in a General Equilibrium Framework. Journal of Public Economics, 39, 83-107. http://dx.doi.org/10.1016/0047-2727(89)90056-X

[14] Ramsey, F.P. (1927) A Contribution to the Theory of Taxation. Economic Journal, 37, 47-61.

[15] Deaton, A.S. (1981) Optimal Taxes and the Structure of Preferences. Econometrica, 49, 1245-1260. http://dx.doi.org/10.2307/1912753

[16] Srinivasan, P.V. (1989) Redistributive Impact of “Optimal” Commodity Taxes. Evidence from Indian Data. Economics Letters, 30, 385-388. http://dx.doi.org/10.1016/0165-1765(89)90097-9

[17] Abed, G.T. (1998) Fiscal Reform in Low-Income Countries: Experience under IMF Supported Programs. IMF Occasional Paper No. 160, 90 p.

[18] Tanzit, V. and Zee H.H. (2000) Tax Policy for Emerging Market: Developing Countries. IMF Working Paper No. WP/00/35, 34 p.

[19] Diamond, P.A. and Mirrlees, J.A. (1971) Optimal Taxation and Public Production 1: Production Efficiency and 2: Tax Rules. American Economic Review, 61, 8-27 and 261-278.

[20] Dixitd, A. (1985) Tax Policy in Open Economies. In: Auerbach, A.J. and Feldsetin, M., Eds., Handbook of Public Economics, Volume I, Elsevier Science Publishers B.V., Amsterdam, 313-374. http://dx.doi.org/10.1016/S1573-4420(85)80009-4

[21] Michael, M.S., Hazipanayotou, P. and Miller, S.M. (1993) Integrated Reform of Tariffs and Consumption Taxes. Journal of Public Economics, 52, 417-428. http://dx.doi.org/10.1016/0047-2727(93)90044-T

[22] Michael, M.S., Hazipanayotou, P. and Miller, S.M. (1994) Win-Win Indirect Tax Reform—A Modest Proposal. Economics Letters, 44, 147-151. http://dx.doi.org/10.1016/0165-1765(93)00315-F 
[23] Keen, M. and Lightartl, J.E. (1999) Coordinating Tariff Reduction and Domestic Tax Reform. IMF Working Paper No. WP/99/93, Juillet, $20 \mathrm{p}$.

[24] Corden, W.M. (1984) The Normative Theory of International Trade. In: Jones, R.W. and Kenen, P.B., Eds., Handbook of International Economics, Volume I, Elsevier Science Publishers B.V., Amsterdam, 63-130. 